\title{
Erratum to: Chronic social isolation is related to both upregulation of plasticity genes and initiation of proapoptotic signaling in Wistar rat hippocampus
}

Ana Djordjevic · Miroslav Adzic · Jelena Djordjevic • Marija B. Radojcic

Published online: 19 November 2009

(C) Springer-Verlag 2009

Erratum to: J Neural Transm

DOI 10.1007/s00702-009-0286-x

Acknowledgments This work was supported by the Ministry of Science and Technological Development of the Republic of Serbia, Grant No. 143042B.

The online version of the original article can be found under doi: 10.1007/s00702-009-0286-x.

\footnotetext{
A. Djordjevic · M. Adzic · J. Djordjevic · M. B. Radojcic $(\bowtie)$ Department of Molecular Biology and Endocrinology,

VINCA Institute of Nuclear Sciences, P.O. Box 522, MBE090, 11001 Belgrade, Serbia

e-mail: marija@vinca.rs
} 